\title{
Lower serum 25-hydroxycholecalciferol is associated with depressive symptoms in older adults in Southern Brazil
}

\author{
Gilciane Ceolin', Luísa Harumi Matsuo', Susana Cararo Confortin² ${ }^{2}$ Eleonora D’Orsi ${ }^{3}$, Débora Kurrle Rieger ${ }^{4,5}$ and \\ Júlia Dubois Moreira ${ }^{4,5^{*}}$ iD
}

\begin{abstract}
Background: Older adults are one of the most susceptible populations to depression, especially those living in low- and middle-income countries. As well, they are also considering a risk group for vitamin D deficiency. Low serum vitamin $\mathrm{D}$ has been associated with an increased risk of brain neuropsychiatry disorders. We aimed to investigate the association between serum 25hydroxycholecalciferol concentrations and depressive symptoms in adults aged 60 years and over from southern Brazil.

Methods: A cross-sectional analysis was performed using data collected during 2013-2014 from the populationalbased longitudinal EpiFloripa Aging Study ( $n=1197)$. Serum 25-hydroxycholecalciferol concentrations were analyzed and classified according to the Endocrine Society reference values [sufficiency ( $\geq 30 \mathrm{ng} / \mathrm{mL}$ ), insufficiency (21-29 ng/ $\mathrm{mL})$, and deficiency $(\leq 20 \mathrm{ng} / \mathrm{mL})]$. Depressive symptoms were evaluated using the Geriatric Depression Scale (15-item GDS). Logistic regression was performed to assess depressive symptoms in each vitamin D category. The analysis was adjusted for sex, age, skin color, family income, leisure-time physical activities, social or religious groups attendance, morbidities, cognitive impairment, and dependence in activities of daily living.
\end{abstract}

Results: A total of 557 participants with complete data for exposure and outcome were enrolled in the analysis. Most of the sample participants were female (63.1\%), age-range 60-69 years (42.2\%), white skin color (85.1\%), and vitamin D serum level samples were collected in autumn (50.7\%). Depressive symptoms were present in $15.8 \%$ of the participants, and the prevalence was higher in individuals classified as deficient in vitamin D $(23.2,95 \%$ confidence interval $[\mathrm{Cl}]=$ 15.6;32.9) and insufficiency $(17.2,95 \% \mathrm{Cl}=11.0 ; 25.9)$. The crude analysis showed that vitamin D deficient participants had $3.08(\mathrm{Cl}=1.53 ; 6.20)$ times higher odds to present depressive symptoms compared to vitamin D sufficiency. After adjusting, the association was maintained [OR $2.27(95 \% \mathrm{Cl}=1.05 ; 4.94)$.

Conclusions: Serum 25-hydroxycholecalciferol deficiency was positively associated with depressive symptoms in older adults from southern Brazil.

Keywords: Vitamin D, Aging, Depressive symptoms, cohort study, Mental health

\footnotetext{
*Correspondence: juliamoreira@gmail.com

${ }^{4}$ Department of Nutrition, Translational Nutritional Neuroscience Working

Group, Postgraduate Program in Nutrition, Federal University of Santa

Catarina, Florianopolis, Brazil

${ }^{5}$ Translational Nutritional Neuroscience Working Group. Postgraduate Program in Nutrition. Department of Nutrition, Universidade Federal de Santa Catarina. Centro de Ciências da Saúde, Campus Universitário Trindade, Florianópolis, Santa Catarina 88040-900, Brazil

Full list of author information is available at the end of the article
}

(c) The Author(s). 2020 Open Access This article is licensed under a Creative Commons Attribution 4.0 International License, which permits use, sharing, adaptation, distribution and reproduction in any medium or format, as long as you give appropriate credit to the original author(s) and the source, provide a link to the Creative Commons licence, and indicate if changes were made. The images or other third party material in this article are included in the article's Creative Commons licence, unless indicated otherwise in a credit line to the material. If material is not included in the article's Creative Commons licence and your intended use is not permitted by statutory regulation or exceeds the permitted use, you will need to obtain permission directly from the copyright holder. To view a copy of this licence, visit http://creativecommons.org/licenses/by/4.0/ The Creative Commons Public Domain Dedication waiver (http://creativecommons.org/publicdomain/zero/1.0/) applies to the data made available in this article, unless otherwise stated in a credit line to the data. 


\section{Introduction}

Despite efforts to reduce the number of people with depressive disorders, their prevalence has increased, particularly in lower-income countries, and depression holds the third position globally in terms of years lived with disability [1,2]. Besides being a debilitating disease for older adults, presenting a variety of emotional and physical problems, its treatment approach involves mainly implementation of preventive health habits and high-cost rehabilitation programs $[3,4]$.

Depression in older adults living in low- and middleincome countries is associated with a higher risk of suicide and excess mortality, more frequent medical consultations and hospitalization, and a significant family burden, even though the number of depressive older adults is similar to that of adults $[3,5,6]$. Additionally, depression is associated with significant adverse consequences ranging from poor quality of life, difficulties with daily living activities (DLA), physical comorbidities, and cognitive impairment [5]. Environmental causes and lifestyle factors, such as obesity, exposure to physical and substance abuse, widowhood, the presence of chronic illnesses and sleep disorders, lack of education and social support, intimate partner, and physical activity have been related to depression [7]. Several mechanisms have been studied in the neurobiology of depression, such as genetic factors, neurotransmitter systems, neuroendocrine systems, inflammation, functional and structural brain anatomy, and cognition $[8,9]$. Some promising studies suggest the involvement of nutritional factors, such as vitamin $\mathrm{D}$, in the development of depressive symptoms [10, 11].

Vitamin D-related effects on homeostasis, neurotrophic, and neuroimmunomodulatory actions appear to be associated to depressive symptoms prevention. However, the exact molecular mechanisms underlying this relationship are not well stablished [12]. Vitamin D is considered a neurosteroid hormone because of its essential role in the central nervous system and connection to processes associated with cell differentiation, neurotrophic factor synthesis and release, neurotransmitter synthesis, intracellular calcium homeostasis, redox balance, neuronal metabolism, and cognitive function [13, 14]. Vitamin D signaling through the nuclear receptors vitamin D receptors (VDR) and the membrane receptor protein disulfide isomerase family member3 (PDIA3), and the presence of some key enzymes of Cytochrome P450, such as CYP27a1, CYP27b1 and CYP24a1, responsible to convert the inactive form of vitamin $\mathrm{D}$ to its active form in the brain cells, as well as its requirements for neuron cell cycle, initiated the investigation of vitamin $\mathrm{D}$ relevance for brain metabolism in health and disease [15-18]. One underlying mechanism proposed is that the vitamin D could regulate serotonin synthesis $[19,20]$. Calcitriol (1,25-dihydroxyvitamin D3) is a key regulator of serotonin, inducing the
TPH2 (tryptophan hydroxylase 2) gene expression, which is the enzyme involved on tryptophan metabolism in the brain to produce serotonin $[19,21]$. Calcitriol also reduce serotonin reuptake transporter (SERT) expression, which is responsible to remove serotonin from synaptic cleft, and monoamine oxidase-A (MAO-A), which is responsible for serotonin catabolism [22]. Calcium homeostasis is another possible mechanism associated to vitamin $\mathrm{D}$ neuroprotection. Its relevance in redox balance and inflammation could also be involved in the relationship between vitamin D and depression [23, 24]. Vitamin D stimulates the expression of many antioxidant genes, such as factor 2 related to the nuclear factor eritroid-2 (NRF2), g-glutamyl transpeptidase (g-GT), glutamate-cysteine ligase (GCLC), glutathione reductase (GR), glutathione peroxidase (Gpx) [23].

Aging process is associated to the reduced ability to sustain homeostasis and more susceptibility to pathological alterations, such as neuropsychiatric disorders $[25,26]$. Understanding the link between vitamin D concentration and depression in aging is required due to be a possible way to minimize the effects of depression. Given the complexity of the condition, more risk to mortality, difficulty in access to treatment, and including that older adults that are undiagnosed $[6,27,28]$. Besides of being considered a risk group for depression, older adults are also one of the risk groups for vitamin $\mathrm{D}$ deficiency due to their reduced skin capacity to synthesize vitamin $\mathrm{D}$, reduced sun exposure, and more significant complications related to low serum vitamin D concentrations $[29,30]$. Some observational studies have investigated the relationship between low serum vitamin D concentrations and depressive symptoms in adulthood or in adults and elderly population combined, and few included only older adults in the sample, as observed by a recently published meta-analyses [31-33].

Therefore, the present study aimed to investigate the association between low serum vitamin D concentrations and depressive symptoms in older adults living in Southern Brazil, as well as elucidate the prevalence of depressive symptoms in this population and the magnitude of the prevalence of vitamin $\mathrm{D}$ deficiency as well. We hypothesized that the low serum of $25(\mathrm{OH}) \mathrm{D}(<20 \mathrm{ng} / \mathrm{ml})$ could be associated with depressive symptoms and we intend to discuss the factors related this association in elderly.

\section{Methods}

\section{Study population and design}

We performed a cross-sectional analysis with data collected in the second wave (2013-2014) of the populational-based EpiFloripa Aging Study. Details about the sample and methodology have been previously published [34, 35]. Briefly, EpiFloripa Aging is a cohort study aiming to investigate health determinants and aspects of the older adult 
population living in Southern Brazil. Older adults of both sexes, aged 60 years or over at the time of the first interview, living in the sectors determined by the survey, were considered eligible at baseline, in 2009 (Fig. 1). Older adults who were institutionalized (residing in long-term care institutions, hospitals, prisons) were excluded.

All the older adults in the follow-up (1197 interviews; retention rate of $70.2 \%$ ) were invited to participate in the second wave of the study (2013-2015), which included biochemical blood analysis (retention rate of $50.5 \% ; n=604$ ) [35]. For this cross-sectional analysis, we enrolled 577 individuals, and the inclusion criteria were to present complete data for depressive symptoms and to be the evaluation of 25hydroxycholecalciferol (Fig. 1).

The EpiFloripa Aging Study's second wave of follow-up was approved by the Human Research Ethics Committee of the Federal University of Santa Catarina (approval protocols numbers: 329.650 and 526.126). Voluntary participation of the individuals was obtained through the signing of the Informed Consent Form, after explaining the study objectives and collection procedures. The EpiFloripa Aging Study was conducted in accordance with the Declaration of Helsinki.

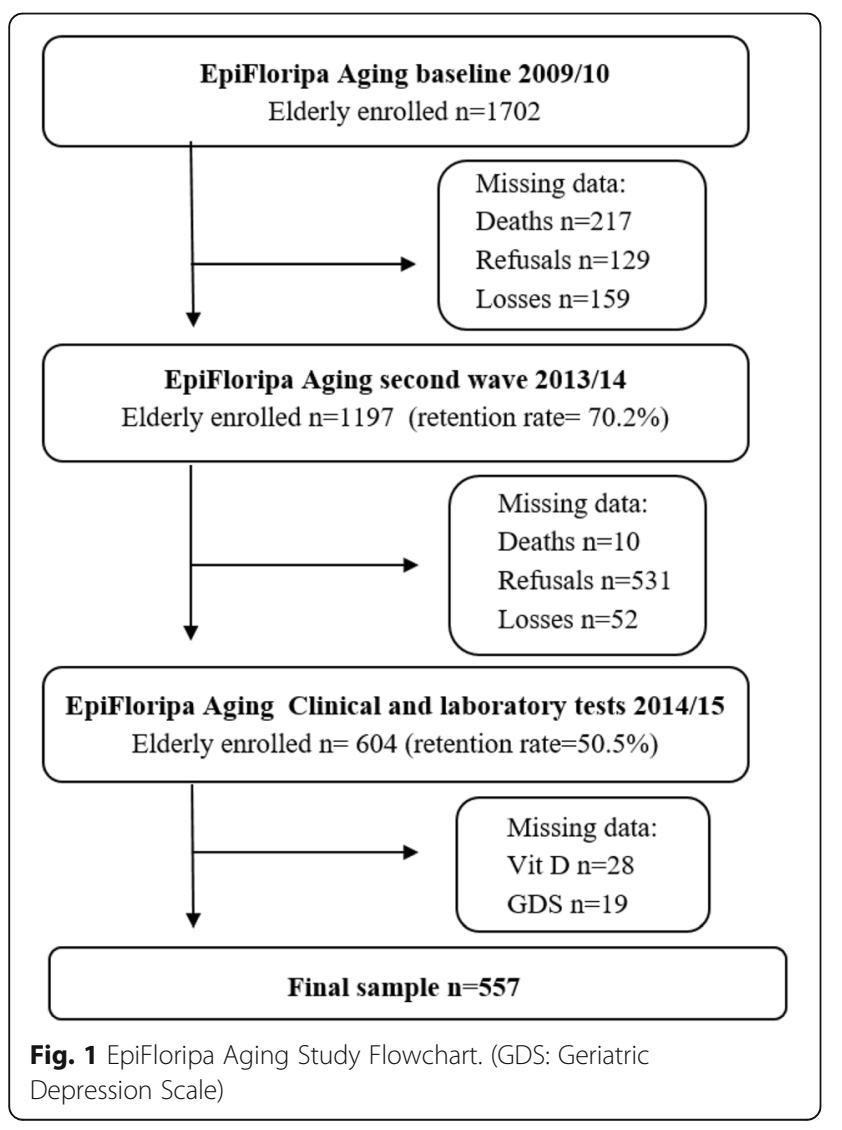

\section{Data collection and covariates}

Trained interviewers conducted data collection at the participant's home. The face-to-face interviews were scheduled with the participants by phone. EpiFloripa Aging Study data were collected using a 15-block questionnaire with socioeconomic, demographic, and health aspects related to aging and prioritizing validated instruments translated and validated in Brazil for the composition of the questionnaire to guarantee the data quality control. The selected interviewers were health science graduates with research experience. Data were recorded in a netbook and transmitted directly to the EpiFloripa database. Quality control was carried out by telephone, using a short version of the questionnaire in $10 \%$ of the samples.

\section{Depressive symptoms}

To evaluate the presence of depressive symptoms, we applied the 15-item Geriatric Depression Scale (15-item GDS). We used the cut-off points suggested by Almeida and Almeida, we classified participants into two groups: those with the presence of depressive symptoms $(\geq 6$ points) and those with the absence of depressive symptoms ( $\leq 5$ points) $[36,37]$.

The GDS-15 is recommended by the Brazilian Ministry of Health, and is a useful alternative for the rapid assessment of the presence of depressive symptoms in the elderly [38]. The GDS-15 was translated and validated in Brazil according to ICD-10 criteria for research and DSM-IV with outpatients aged 60 or over who met criteria for depressive disorder (current or in remission) $[36,39]$. The cutoff point 5/6 (not case/case) produced sensitivity indexes of $85.4 \%$ and specificity of $73.9 \%$ according to ICD-10 and $90.9 \%$ of sensitivity and $64.5 \%$ of specificity according to the DSM-IV and the internal consistency using Cronbach's alpha coefficient revealed reliability indexes of 0.81 [39]. Moreover, in the testretest reliability when the outpatient was evaluated twice in 48 to $72 \mathrm{~h}$, and GDS-15 scores were reasonably stable, as assessed by paired Wilcoxon $(\mathrm{z}=1.60, p=0.109)$ and Spearman's correlation coefficient ( $(\mathrm{hho}=0.86, p<0,001)$ and weighted Kappa (Kappa $=0.64)$ [36].

\section{Serum vitamin D (25-hydroxycholecalciferol) concentrations}

For the measurement of 25-hydroxycholecalciferol [25(OH)D] blood samples were collected at the University Laboratory for Metabolism and Dietetics, between 7 and 10 a.m., with the required minimum of $8 \mathrm{~h}$ fasting period before the procedure [35]. Blood samples were centrifuge $(3.500 \mathrm{rpm})$ for $10 \mathrm{~min}$. Serum samples used to detect $25(\mathrm{OH})$ D were immediately processed using LIASON ${ }^{\circledR} 25$ $\mathrm{OH}$ vitamin D assay (Diasorin, São Paulo, Brazil) accordingly to manufacture (Functional Sensitivity: $\leq 2.0 \mathrm{ng} / \mathrm{mL}$; 
(inter-assay imprecision $<20 \%$ ), which is considered $\mathrm{s}$ a rapid, accurate, and precise assay [40]. Briefly, an antibody specific to vitamin D was coated on magnetic particles, and 25-OHD conjugated to an isoluminol derivative and diluted in phosphate buffer ( $\mathrm{pH}$ 7.4). In the first incubation period, 25-OHD dissociated from the binding protein, and it interacts with the antibody. After the second incubation with the tracer reagent, microplate is washed with the buffer and starter reagents are added to generate the chemiluminescent signal, which is measured by a photomultiplier. Serum $25(\mathrm{OH}) \mathrm{D}$ concentrations were measured using the Microparticle Chemiluminescence method/LIAISON [41]. Subsequently, we categorized serum $25(\mathrm{OH})$ D concentrations according to the Endocrine Society Reference values [42] into: sufficiency ( $\geq 30 \mathrm{ng} / \mathrm{mL})$, insufficiency $(21-29 \mathrm{ng} / \mathrm{mL})$, and deficiency $(\leq 20 \mathrm{ng} / \mathrm{mL})$.

\section{Covariates}

For characterization of the samples, we analyzed sociodemographic variables, such as sex (male/female), skin color (white/not white), the season during blood collection (summer/autumn/winter/spring), age range (aged $60-69 / 70-79 / \geq 80$ years), education (no formal education/1-4/5-8/9-11/ $\geq 12$ years), per capita family income in minimal wages according to the values in 2013 ( R\$ $678.00)$ and $2014(\mathrm{R} \$ 724.00)(\leq 1 />1$ to $\leq 3 />3$ to $\leq 5 />5$ to $\leq 10 />10$ ), retired (no/yes), living arrangements (live with another/alone) and marital status (married/single/ divorced/widowed). Behavioral modified factors were included in the analysis, such as belonging to a social or religious group (no/yes), smoking (no/yes), alcohol consumption (no/yes) collected by Alcohol Use Disorder Identification Test [43]. Leisure-time physical activity (insufficiently active $<150 \mathrm{~min}$ or sufficiently active $\geq 150 \mathrm{~min}$ ) collected by the International Physical Activity Questionnaire [44, 45].

Health status-related information included dependence in the activities of daily living (ADLs) [no disability, low disability (any level of disability in 1 to 3 activities), and moderate/severe disability (any level of disability in $\geq 4$ activities)] collected by the scale of daily basic and instrumental activities [46]. Screening for cognitive impairment was evaluated using the Mini-Mental State Examination (absence/presence-considering schooling, using the cut-off points $19 / 20$ for illiterate and 23/24 for any level of education) $[47,48]$. The number of comorbidities were assessed [zero/1/ $\geq 2$ (sum of diagnosed diseases: spine or back pain, arthritis, cancer, diabetes, bronchitis, cardiovascular or renal conditions, tuberculosis, cirrhosis, stroke, osteoporosis, hypertension, and depression)]. Nutritional status was assessed by body mass index (underweight $<22 \mathrm{~kg} / \mathrm{m}^{2}$; healthy weight 22$27 \mathrm{~kg} / \mathrm{m}^{2}$; overweight $>27 \mathrm{~kg} / \mathrm{m}^{2}$ ), according to the $\mathrm{Nu}$ trition Screening Initiative [49]. Information about antidepressant drug use and vitamin D supplement use was collected by consulting all boxes of medicines prescribed for and used by the participant. The Anatomical Therapeutic Chemical Classification codes from the World Health Organization Collaborating Centre for Drug Statistic Methodology were applied for codification in the database [50].

\section{Statistical analysis}

Descriptive analysis of the data was presented as absolute and relative frequency, prevalence, and respective 95\% confidence intervals (CI) for the total sample based on the presence of depressive symptoms. The distribution of the covariates was determined using the chisquare test. We performed Student's t-test to verify the mean differences between sex and depressive symptoms in serum 25(HO) D concentrations.

Logistic regression was used to evaluate the odds ratio (OR) for depressive symptoms in each $25(\mathrm{HO}) \mathrm{D}$ category and the respective $\mathrm{CI}$ in the crude and adjusted association models. The covariates were included following a hierarchical model (first socioeconomic covariates, followed by behavioral covariates, and finally, health covariates). Model 1 was adjusted for demographic and socioeconomic variables (sex, skin color, age range, and family income). Model 2 included demographic, socioeconomic, and behavioral variables (leisure-time physical activities and social or religious groups attendance). Model 3 included demographic, socioeconomic, behavioral, and health variables (morbidities, cognitive impairment, dependence in activities of daily living).

The analysis was performed using Stata 14.0 software (StataCorp, College Station, TX, USA). Due to the sampling design (two-stage cluster) of the EpiFloripa Aging Study, sample weights were used in all the analyses, using the "svy" command. $P$-value $<0.05$ was used to define statistical significance for all reports.

\section{Results}

Of the 604 older adults who participated in clinical and laboratory tests in 2014-2015, 577 individuals met the criteria and presented complete data to be included in the analysis (Fig. 1). Sample characteristics are summarized according to the prevalence of depressive symptoms in Table 1. For the total sample, the prevalence of depressive symptoms was $15.8 \%$, and the prevalence of $25(\mathrm{OH}) \mathrm{D}$ was 39.4 and $25.5 \%$ in insufficiency and deficiency cases, respectively.

Individuals with presence of depressive symptoms were mostly women $(18.2 \% P=0.006)$, aged $\geq 80$ years (22.2\%; $P=0.009)$, with $\leq 4$ years of formal education (19.5;17.5\%; $P=0.016)$, lower per capita family income $\leq 1$ minimum wage $(22.4 \% ; \quad P=0.002)$, insufficient leisure-time physical activity $(19.3 \%$; $P<0.001)$, more dependency in ADLs $(30.8 \% ; P<0.001)$, presence of 
Table 1 Prevalence of depressive symptoms according to demographic, socioeconomic, behavioral, and health characteristics

\begin{tabular}{|c|c|c|c|c|c|}
\hline \multirow[t]{2}{*}{ Characteristics $(n=557)$} & \multicolumn{2}{|c|}{ Total } & \multicolumn{3}{|c|}{ Presence of depressive symptoms } \\
\hline & $\mathbf{n}$ & $\%$ & $\%$ & $95 \% \mathrm{Cl}$ & $P$-value \\
\hline Sex & & & & & 0.006 \\
\hline Men & 194 & 36.9 & 11.7 & $6.4 ; 20.6$ & \\
\hline Women & 363 & 63.1 & 18.2 & $13.5 ; 24.0$ & \\
\hline Skin Color & & & & & 0.077 \\
\hline White & 468 & 85.1 & 14.1 & $9.9 ; 19.7$ & \\
\hline Not white & 89 & 14.9 & 25.5 & $16.6 ; 37.0$ & \\
\hline Season (Vit. D collection) & & & & & 0.791 \\
\hline Summer & 55 & 9.1 & 14.4 & $6.7 ; 28.0$ & \\
\hline Autumn & 276 & 50.7 & 18.1 & $11.4 ; 27.5$ & \\
\hline Winter & 145 & 23.6 & 14.8 & $10.2 ; 21.0$ & \\
\hline Spring & 81 & 16.6 & 11.1 & $5.1 ; 22.5$ & \\
\hline Age range (years) & & & & & $0.009^{*}$ \\
\hline $60-69$ & 236 & 42.2 & 12.4 & $7.2 ; 20.5$ & \\
\hline 70-79 & 235 & 41.8 & 16.8 & $11.6 ; 23.8$ & \\
\hline$\geq 80$ & 86 & 16,0 & 22.2 & $14.3 ; 32.9$ & \\
\hline Education (years) & & & & & 0.016 \\
\hline No formal education & 35 & 5.5 & 17.5 & $8.4 ; 32.9$ & \\
\hline $1-4$ & 199 & 33.7 & 19.5 & $13.3 ; 27.5$ & \\
\hline $5-8$ & 100 & 19.2 & 14.9 & $8.4 ; 25.2$ & \\
\hline $9-11$ & 86 & 17.8 & 18.5 & $7.8 ; 38.0$ & \\
\hline$\geq 12$ & 137 & 23.8 & 8.9 & $4.3 ; 17.7$ & \\
\hline Per capita family income $(n=539)$ & & & & & $0.002^{*}$ \\
\hline$\leq 1 \mathrm{mw}$ & 40 & 6.4 & 22.4 & $11.8 ; 38.6$ & \\
\hline$>1$ and $\leq 3 \mathrm{mw}$ & 156 & 30.3 & 20.6 & $13.7 ; 29.7$ & \\
\hline$>3$ and $\leq 5 \mathrm{mw}$ & 108 & 17.5 & 19.3 & $11.1 ; 31.3$ & \\
\hline$>5$ and $\leq 10 \mathrm{mw}$ & 136 & 26.4 & 10.9 & $5.6 ; 20.1$ & \\
\hline$>10 \mathrm{mw}$ & 99 & 19.4 & 9.9 & $4.8 ; 19.2$ & \\
\hline Retirement $(n=521)$ & & & & & 0.152 \\
\hline No & 102 & 19.9 & 21.8 & $11.5 ; 37.1$ & \\
\hline Yes & 419 & 80.1 & 14.4 & $10.8 ; 19.0$ & \\
\hline Living arrangements & & & & & 0.547 \\
\hline Live with another/others & 445 & 78.7 & 16.0 & $12.0 ; 21.0$ & \\
\hline Live alone & 112 & 21.3 & 15.2 & $8.3 ; 26.1$ & \\
\hline Marital Status & & & & & 0.095 \\
\hline Married & 317 & 56.5 & 11.6 & $7.7 ; 17.2$ & \\
\hline Single & 33 & 6.1 & 20.9 & $7.0 ; 48.3$ & \\
\hline Divorced & 45 & 9.3 & 27.1 & $14.5 ; 44.8$ & \\
\hline Widowed & 162 & 28.1 & 19.4 & $13.4 ; 17.3$ & \\
\hline Social and religious groups attendance & & & & & 0.114 \\
\hline No & 298 & 56.3 & 18.2 & $13.1 ; 24.8$ & \\
\hline Yes & 259 & 43.7 & 12.7 & $8.6 ; 18.4$ & \\
\hline Alcohol Consumption & & & & & $<0.001$ \\
\hline No & 319 & 56.0 & 19.0 & $13.8 ; 25.7$ & \\
\hline
\end{tabular}


Table 1 Prevalence of depressive symptoms according to demographic, socioeconomic, behavioral, and health characteristics (Continued)

\begin{tabular}{|c|c|c|c|c|c|}
\hline \multirow[t]{2}{*}{ Characteristics $(n=557)$} & \multicolumn{2}{|c|}{ Total } & \multicolumn{3}{|c|}{ Presence of depressive symptoms } \\
\hline & $n$ & $\%$ & $\%$ & $95 \% \mathrm{Cl}$ & $P$-value \\
\hline Yes & 238 & 44.0 & 11.7 & $6.7 ; 19.6$ & \\
\hline Smoking & & & & & 0.307 \\
\hline No & 351 & 58.6 & 17.0 & $12.2 ; 23.3$ & \\
\hline Yes & 206 & 41.4 & 14.1 & $10.1 ; 19.3$ & \\
\hline Leisure-time physical activity $(n=556)$ & & & & & $<0.001$ \\
\hline Insufficiently active & 395 & 70.7 & 19.3 & $14.7 ; 24.8$ & \\
\hline Sufficiently active & 161 & 29.3 & 7.4 & $3.5 ; 14.8$ & \\
\hline Dependence in ADLs $(n=554)$ & & & & & $<0.001^{*}$ \\
\hline None & 202 & 38.1 & 6.4 & $3.2 ; 12.4$ & \\
\hline Low & 217 & 37.5 & 15.1 & $9.7 ; 22.7$ & \\
\hline Moderate/severe & 135 & 24.4 & 30.8 & $21.4 ; 42.1$ & \\
\hline Cognitive impairment $(n=554)$ & & & & & $<0.001$ \\
\hline Absent & 442 & 79.6 & 10.9 & $7.3 ; 15.9$ & \\
\hline Present & 112 & 20.4 & 34.0 & $23.6 ; 46.1$ & \\
\hline Number of comorbidities & & & & & $<0.001$ \\
\hline Zero & 34 & 6,0 & 13.5 & $2.8 ; 46.2$ & \\
\hline 1 & 96 & 18.6 & 1.4 & $0.3 ; 5.7$ & \\
\hline$\geq 2$ & 427 & 75.4 & 19.5 & $15.1 ; 24.9$ & \\
\hline Nutritional status BMI $(n=554)$ & & & & & 0.061 \\
\hline Underweight & 45 & 8.2 & 23.3 & $12.3 ; 39.7$ & \\
\hline Healthy Weight & 256 & 44.3 & 11.8 & $7.7 ; 17.8$ & \\
\hline Overweight & 253 & 47.5 & 18.0 & $12.6 ; 25.1$ & \\
\hline Antidepressant use $(n=529)$ & & & & & 0.048 \\
\hline No & 449 & 85.4 & 15.4 & $11.2 ; 20.7$ & \\
\hline Yes & 80 & 14.6 & 21.4 & $12.4 ; 34.4$ & \\
\hline Vitamin D supplement use $(n=521)$ & & & & & 0.232 \\
\hline No & 464 & 90.6 & 16.6 & $12.1 ; 22.2$ & \\
\hline Yes & 57 & 9.4 & 11.5 & $4.8 ; 25.1$ & \\
\hline Serum $25(\mathrm{OH}) \mathrm{D}$ & & & & & $0.006^{*}$ \\
\hline Sufficiency & 188 & 35.1 & 8.9 & $4.8 ; 15.9$ & \\
\hline Insufficiency & 226 & 39.4 & 17.2 & $11.0 ; 25.9$ & \\
\hline Deficiency & 143 & 25.5 & 23.2 & $15.6 ; 32.9$ & \\
\hline \multicolumn{6}{|l|}{ Depressive Symptoms } \\
\hline Absent & 467 & 84.2 & - & & \\
\hline Present & 90 & 15.8 & - & & \\
\hline
\end{tabular}

mw minimum wage, $A D L s$ activities of daily living, $B M I$ Body Mass Index, $C l$ confidence interval; $P$-value, statistical significance; ${ }^{*} P$-value of chi-square test for trend

cognitive impairment $(34.0 \% ; P<0.001)$; and reported 2 or more comorbidities $(19.5 \% P<0.001)$. Considering the Endocrinology Society reference values for $25(\mathrm{OH})$ $\mathrm{D}$, a higher prevalence of depressive symptoms was observed in those with vitamin $\mathrm{D}$ deficiency than in those with sufficiency $(23.8 \%$ vs. $8.9 \%$ respectively; $P=0.006)$.
On average, women presented lower serum $25(\mathrm{OH}) \mathrm{D}$ concentrations than men $(P=0.001)$, and individuals with depressive symptoms also showed lower concentrations $(P=0.005)$ (Table 2).

In Table 3, we present the crude and adjusted association analysis between serum $25(\mathrm{OH}) \mathrm{D}$ concentrations 
Table 2 Serum 25(OH) D concentrations according to sex and depressive symptoms

\begin{tabular}{lccr}
\hline & \multicolumn{3}{c}{ Serum 25(OH) D $(\mathbf{n g} / \mathrm{mL})$} \\
\cline { 2 - 4 } & Mean & $\mathbf{9 5 \% \mathrm { Cl }}$ & $\boldsymbol{P}$-value \\
\hline Sex & 28.7 & $27.3 ; 30.2$ & $<0.001$ \\
$\quad$ Men & 25.4 & $24.5 ; 26.2$ & \\
$\quad$ Women & & & 0.005 \\
Depressive Symptom & 27.0 & $26.2 ; 27.8$ & \\
$\quad$ Absent & 24.1 & $22.2 ; 26.0$ & \\
$\quad$ Present &
\end{tabular}

$\mathrm{Cl}$ Confidence interval; $P$-value, statistical significance using Student's T-Test

and depressive symptoms. In the crude analysis, we found that vitamin D-deficient individuals presented 3.08 times higher OR (CI $95 \%=1.53 ; 6.20)$ of depressive symptoms than those with sufficient concentrations. After adjusting for demographic, socioeconomic, behavioral, and health covariates (model 3), vitamin D-deficient individuals presented 2.27 times higher OR (CI 95\% = 1.05; 4.94) of depressive symptoms than those considered sufficient.

\section{Discussion}

In the present study, we observed a statistically significant association between serum $25(\mathrm{OH}) \mathrm{D}$ deficiency and depressive symptoms in the older adult population living in one capital of southern Brazil, even after adjustments for potential confounding factors related to demographic, socioeconomic, behavioral, and health variables. Vitamin D deficient individuals had 2.7 times higher odds of depressive symptoms. We also found that $15.8 \%$ of the population enrolled in the analysis presented depressive symptoms, using the 15-item GDS; thus, showing the importance of screening for depression symptoms in this population.

There is little evidence published in the literature about vitamin D deficiency in older adults and its relationship with neuropsychiatric disorders, especially studies that used a population-based sample, as presented here. Until May 2020, we found 10 other studies with cross-sectional analysis performed with older adults [51-60], one of these with longevous individuals (aged > 100 years) [42], and two were conducted only with men
$[57,58]$. We identified 13 cross-sectional studies conducted with a mixed population of adults and older adults [61-73]. Only two studies were performed in lowand middle-income countries [61,72], which are the most affected by depression accordingly to World Health Organization [1]. We concluded that there is a gap in the literature about investigations involving depressive symptoms in low- and middle-income countries. This was a relevant aspect because socioeconomic covariates, such as low per capita family income and fewer years of formal education, were related to a higher prevalence of depressive symptoms in our sample, and were a universal life situation for the populations living in low- and middle-income countries [74, 75].

Older adults are considered a risk group for hypovitaminosis $\mathrm{D}$ due to the reduction in vitamin $\mathrm{D}$ absorption and synthesis, modification in food intake that could reduce vitamin $\mathrm{D}$ ingestion, and reduced outdoor activity that favors sunlight-derived vitamin D synthesis [29, 7678]. A study comparing two cohorts from the Longitudinal Aging Study Amsterdam (LASA), one with adults aged 55-65 years $(n=737)$ and other with older adults aged 65 years or older $(n=1282)$, found a higher $25(\mathrm{OH}) \mathrm{D}$ concentrations in the younger group, better physical functioning, fewer chronic diseases, and they were more physically active compared with the older ones [73].

In our sample, $70.7 \%$ of the participants who reported reduced leisure physical activity and 19\% of those who presented with depressive symptoms were classified as vitamin D insufficient (data not shown). These data were consistent with the literature review. A recent metaanalysis showed that people with depression were less physically active than the corresponding controls, and about $80 \%$ of people with depression were unable to achieve the recommended weekly physical activity [79]. A previous study found that less physical activity was associated with reduced vitamin D concentrations and modestly attenuated the OR for depression in the adjusted analysis [52]. Another study provided evidence for the potential mediating role of physical functioning in the relationship between low $25(\mathrm{OH}) \mathrm{D}$ levels and increasing of depressive symptoms [73].

Table 3 Crude and adjusted measures of association between serum 25(OH) D concentrations and depressive symptoms

\begin{tabular}{|c|c|c|c|c|c|c|c|c|c|c|c|c|}
\hline \multirow{2}{*}{$\begin{array}{l}\text { Serum } \\
25(O H) D^{1}\end{array}$} & \multicolumn{3}{|c|}{ Crude Analysis } & \multicolumn{3}{|c|}{ Model $1^{2}$} & \multicolumn{3}{|c|}{ Model $2^{3}$} & \multicolumn{3}{|c|}{ Model 3 (final) ${ }^{4}$} \\
\hline & OR & $95 \% \mathrm{Cl}$ & $p$ & OR & $95 \% \mathrm{Cl}$ & $p$ & OR & $95 \% \mathrm{Cl}$ & $p$ & OR & $95 \% \mathrm{Cl}$ & $p$ \\
\hline Sufficiency & 1 & & & & & & 1 & & & 1 & & \\
\hline Insufficiency & 2.12 & $0.95 ; 4.74$ & 0.067 & 1.86 & $0.77 ; 4.52$ & 0.166 & 1.78 & $0.71 ; 4.50$ & 0.217 & 2.08 & $0.78 ; 5.50$ & 0.138 \\
\hline Deficiency & 3.08 & $1.53 ; 6.20$ & 0.002 & 2.82 & $1.37 ; 5.81$ & 0.005 & 2.61 & $1.22 ; 5.60$ & 0.014 & 2.27 & $1.05 ; 4.94$ & 0.038 \\
\hline
\end{tabular}

${ }^{1}$ References by the Endocrine Society; ${ }^{2}$ Model 1 was adjusted by demographic and socioeconomic factors (sex, skin color, age range, family income); ${ }^{3}$ Model 2 was adjusted by demographic, socioeconomic, and behavioral factors (leisure-time physical activities and social or religious groups attendance); ${ }^{4}$ Model 3 was adjusted by demographic, socioeconomic, behavioral, and health factors (morbidities, cognitive impairment, dependence in activities of daily living). OR, odds ratio; $\mathrm{Cl}$, confidence interval 
We found a relationship between sex and the mean $25(\mathrm{OH}) \mathrm{D}$ concentration. Women presented lower levels than men, but we could not perform a stratified analysis by sex due to the small number of observations in the variable categories for men. However, we included sex as an adjustment variable in the investigation. Previous studies described sex differences showing generally lower $25(\mathrm{OH}) \mathrm{D}$ concentrations in women than in men [51-53, 55, 73, 80]. The sex difference is not yet clearly understood, but is considered to be related to sunscreen use and body fat mass $[78,81,82]$. In our study (data not shown), overweight was found to have a higher prevalence in women $(68.8 \%$ vs. $31.2 \%$ women and men, respectively; $P=0.012$ ) and those with hypovitaminosis D (43.9, 29.6 and $26.5 \%$ in insufficiency, deficiency, and sufficiency, respectively, $P=0.001$ ).

In our study, we observed a prevalence of $\sim 15 \%$ for depressive symptoms, which was considered a high prevalence [1]. Other studies that evaluated depressive symptoms using the GDS screening tool, also showed higher prevalence: $27.9 \%$ in South Korea (sample included individuals aged $\geq 65$ years; $n=2853$ ) [53]; $25.2 \%$ in England (sample included those aged $\geq 65$ years; $n=$ 2070) [54], and $32.2 \%$ in China $(n=940)$ [56]. One study performed in the Netherlands found 7\% prevalence (sample included individuals aged $\geq 65$ years; $n=2839$ ) [59]. In our study, women presented a higher prevalence (18\%) of depressive symptoms, which could indicate this group's greater vulnerability for depression. The studies mentioned above also showed a higher prevalence $30.9 \%$ vs. $21,9 \%$ [ 53 ], $35.6 \%$ vs. $17.7 \%$ [56], and $40,6 \%$ vs. $23.8 \%$ in women vs. men, respectively, the last one being an Italian sample (individuals aged $\geq 65$ years; $n=1.675$ ) [40].

The prevalence of depressive symptoms presented an inverse trend in $25(\mathrm{OH}) \mathrm{D}$ concentrations with $8.9 \%$ of individuals with levels $\geq 30 \mathrm{ng} / \mathrm{mL}, 17.2 \%$ with $21-29 \mathrm{ng} / \mathrm{mL}$, and $23.2 \%$ with $\leq 20 \mathrm{ng} / \mathrm{mL}$. Our findings were lower than those of a previous study. We determined $22.6 \%$ with levels $<30 \mathrm{ng} / \mathrm{mL}, 25.8 \%$ with $<20 \mathrm{ng} / \mathrm{mL}$, and $35.0 \%$ with $<10 \mathrm{ng} / \mathrm{mL}$ levels of serum concentration [54]; however, they followed the same trend. In general, studies demonstrated that a lower serum vitamin D level was associated with a higher prevalence of depressive symptoms, even when other reference values were used $[6 \%$ with $>71.7$ $\mathrm{nmol} / \mathrm{L} ; 4.6 \%$ with $53.4-71.7 \mathrm{nmol} / \mathrm{L}$; $5 \%$ with $36.7-53$ $\mathrm{nmol} / \mathrm{L}$; and $11 \%$ with $<36.7 \mathrm{nmol} / \mathrm{L}$ [59]; as well as $7.8 \%$ with $\geq 30.0 \mathrm{ng} / \mathrm{mL} ; 27.4 \%$ with $20.0-29.9 \mathrm{ng} / \mathrm{mL} ; 50.1 \%$ with $10.0-19.9 \mathrm{ng} / \mathrm{mL}$; and $14.7 \%$ with $<10.0 \mathrm{ng} / \mathrm{mL}$ [53]. The higher chance of depressive symptoms in older adults with low $25(\mathrm{OH}) \mathrm{D}$ concentrations was consistent with previous cross-sectional studies' results $[51,54,56,59$, 60]. In Amsterdam, the Netherlands, in a populationbased sample ( $\geq 65$ years; $n=1282$ ), the severity of depressive symptoms evaluated using the Center for Epidemiologic Studies Depression Scale (CES-D) was associated with decreased serum 25(OH) D concentrations $(\mathrm{B}=9.6$; $95 \% \mathrm{CI}=16.9 ; 2.4 ; p=0.01$ ) [51]. In England, in a Health Survey with older adults ( $\geq 65$ years; $n=2070$ ), depressive symptoms evaluated by 10 -item GDS were associated with clinical vitamin D deficiency $(25(\mathrm{OH})$ D levels $<10 \mathrm{ng} / \mathrm{mL}$ $(\mathrm{OR}=1.46 ; 95 \% \mathrm{CI}=1.02 ; 2.08 ; p=0.04)$ [54]. Data from the English Longitudinal Study of Aging ( $\geq 50$ years; $n=$ 5870 ) showed a significant association between low $25(\mathrm{OH}) \mathrm{D}$ concentrations and depressive symptoms (CESD) $[\mathrm{OR}=1.58 ; 95 \% \mathrm{CI}=1.20-2.07$ for the lowest quartile; $\mathrm{OR}=1.45,95 \% \mathrm{CI}=1.15 .1 .83$ for $\leq 30-\mathrm{nmol} / \mathrm{L}$ cut-off and $\mathrm{OR}=1.34,95 \% \mathrm{CI}=1.10-1.62$ for the $\leq 50 \mathrm{nmol} / \mathrm{L}$ cut-off $)]$ [63].

Although depression has well-studied pathophysiology, the biochemical mechanisms involved in the relationship between vitamin $\mathrm{D}$ and depression are still not well elucidated. Some mechanisms of vitamin D have been suggested, such as changes in glutamatergic neurotransmitter and monoaminergic systems, interactions with inflammatory processes, and control of the expression of those genes that are responsible for maintaining both $\mathrm{Ca} 2+$ and reactive oxygen species homeostasis [23]. Additionally, VDR was found in the prefrontal cortex and parts of the limbic system, and these brain areas had been implicated in the pathophysiology of depression [17].

Another interesting finding in our study was that $21.4 \%(P=0.048)$ of older individuals who used antidepressant drugs were classified as having depressive symptoms. Some studies discussed that around 10$30 \%$ of individuals with depression presented resistance in drug therapy, not responding to treatment with at least two antidepressants [9, 83-85]. Alternatively, the available antidepressants are commonly accompanied by unpleasant side effects and may cause treatment to be discontinued [33]. Additionally, sometimes unintentional non-adherence, such as forgetting and inability to follow treatment instructions because of poor understanding or physical problems (poor eyesight or impaired manual dexterity), was found to be responsible for treatment discontinuation [86].

In our study we did not perform an evaluation about the influence of antidepressant in $25(\mathrm{OH}) \mathrm{D}$ concentration, but some findings point to a relationship in antidepressant use and low level of vitamin D $[87,88]$. The mechanism is not well explained, but there are a hypothesis that tricyclic antidepressant may dampen 1- $\alpha$-hydroxylase activity and induce the activity of 1,25- $(\mathrm{OH}) 2$ vitamin D3 24-hydroxylase [87]. If this hypothesis is verified, perhaps this influence of the antidepressant on the level of vitamin D could lead to a risk of depression.

Furthermore, only $9.4 \%$ of older adults diagnosed with vitamin D insufficiency or deficiency (39.4 and 25.5\%, 
for insufficiency and deficiency, respectively) were using vitamin $\mathrm{D}$ supplements. At the same time, the prevalence of hypovitaminosis $(<30 \mathrm{ng} / \mathrm{mL})$ was present in $>$ $50 \%$ of the total sample. These results offer crucial evidence for the lack of vitamin D supplementation in this population.

A growing body of literature has investigated the potential effect of vitamin D on depression and its promising results, such as its prospective role as an adjuvant in drug therapy [89-92]. This issue is still controversial and may be explained by several methodological differences, such as self-reported diagnosis for depression, different vitamin $D$ reference values used, and various methods for serum vitamin D analysis [33, 93-95]. Further studies are needed to confirm these findings, and vitamin D supplementation may become a convenient and low-cost treatment $[33,91]$. Moreover, depression is a disease requiring high treatment costs; therefore, there is a substantial gap in the necessity and availability of therapy; consequently, a significant population of depressed individuals are left untreated in low- and middle-income countries [28, 96]. Prevention has the potential to reduce not only recurrences, but also initial episodes, thus reducing the prevalence of period and in a lifetime [97].

Our study presented some limitations. It is essential to mention that the blood tests were performed with a part of the total EpiFloripa Study sample, and this may have limited some of the analyses, such as sex stratification. Clinical and biochemical examinations were conducted at the university, which could select individuals with relatively better health conditions than those from the general population. Although important, the crosssectional analyzes should be considered with caution due to their methodological limitations inherent in obtaining data. In addition, longitudinal analysis of this data is in progress for a future study.

As for the strengths of this study, we consider that selecting a sample that includes only older adults is one of them because the population is distinct, considering metabolic alterations and life cycle aspects. Aging is a particular physiological phase of the life cycle, in which people reduce their metabolic ability to sustain homeostasis, which renders them highly susceptible to pathological alterations, especially concerning neuropsychiatric disorders $[25,26]$. Additionally, we analyzed covariates, such as skin color, ethnicity, and the season in which the blood was collected. The 15-item GDS, which evaluates depressive symptoms, is one of the most widely used screening tools in similar studies and has been validated for application in the Brazilian population. Our study followed a highly accurate method for the quality of the data (trained and supervised interviewers, pilot study, face-to-face interviews, and interview quality control).

\section{Conclusion}

In summary, our findings showed that lower serum $25(\mathrm{OH}) \mathrm{D}$ concentrations were independently associated with depressive symptoms in older adults living in Southern Brazil, even after adjusting for demographic, socioeconomic, behavioral, and health variables. These findings are relevant, given the high prevalence of hypovitaminosis $\mathrm{D}$ established among this population. We observed that few older adults classified as vitamin D insufficient/deficient were using supplements, pointing to the necessity of serum vitamin D monitoring and prescription, when necessary, for prevention of not only depressive symptoms, but also other well-known conditions, such as compromised bone health. To better elucidate this relationship, a future longitudinal analysis would also be important and should be validated in more detail animal and cell experiments.

\section{Abbreviations \\ 25(OH)D: 25-hydroxyvitamin D; BMl: Body mass index; OR: Odds ratio; $\mathrm{Cl}$ : Confidence interval; MW: Minimum wage; ADLs: Activities of daily living; GDS: Geriatric depression scale; CES-D: Center for epidemiologic studies depression scale; TPH2: tryptophan hydroxylase 2; SERT: serotonin reuptake transporter; MAO-A: monoamine oxidase-A; PDIA3: protein disulfide isomerase family member3; VDR: vitamin D receptors; DLA: daily living activities; NFR2: nuclear factor eritroid-2; g-GT: g-glutamyl transpeptidase; GCLC: glutamate-cysteine ligase; GR: glutathione reductase; Gpx: glutathione peroxidase; ICD-10: International Statistical Classification of Diseases and Related Health Problems-10 revision; DSM-IV: Diagnostic and Statistical Manual of Mental Disorders- 5th revision}

\section{Acknowledgments}

We are grateful to the participants, interviewers, and researchers from the EpiFloripa Aging Study.

\section{Authors' contributions}

All authors contributed to the study conception and design and takes responsibility for the integrity of the data and the accuracy of the data analysis. Data collection were performed by [ED], [SCC], [JDM], and analysis were performed by [GC]. Material preparation and the first draft of the manuscript was written by [GC] and all authors commented on previous versions of the manuscript. All authors read and approved the final manuscript.

\section{Funding}

This study was supported by partnerships established with the Federal University of Santa Catarina (UFSC), other research projects, and assistance from students and teachers involved in the research. All the infrastructure and instruments needed to carry out the research were made available by the proposing institution, UFSC, with the exception of the netbooks used for data collection that were provided by the Oswaldo Cruz Foundation (FIOCRUZ) in Rio de Janeiro. The stage of collecting clinical and laboratory exams was financed by the Conselho Nacional de Desenvolvimento Científico e Tecnológico (CNPq), process number 475.904 / 2013-3, and developed within the scope of the Postgraduate Program in Collective Health at UFSC. This study was financed in part by the Coordenação de Aperfeiçoamento de Pessoal de Nível Superior - CAPES/Brasil (Finance Code 001).

\section{Availability of data and materials}

The datasets during and/or analyzed during the current study are available from the corresponding author on reasonable request.

Ethics approval and consent to participate

The study was conducted according to the guidelines laid down in the Declaration of Helsinki and was approved by the Ethics Committee of the 
Federal University of Santa Catarina (protocol approval numbers 329.650 and 526.126). All participants provided informed consent prior to participation.

\section{Consent for publication}

All authors read and approved the final manuscript.

\section{Competing interests}

The authors declare that they have no competing of interest.

\section{Author details}

${ }^{1}$ Postgraduate Program in Nutrition, Federal University of Santa Catarina, Florianopolis, Brazil. ${ }^{2}$ Postgraduate Program in Public Health, Federal University of Maranhão, Maranhão, Brazil. ${ }^{3}$ Department of Public Health, Postgraduate Program in Public Health, Federal University of Santa Catarina, Florianopolis, Brazil. ${ }^{4}$ Department of Nutrition, Translational Nutritional Neuroscience Working Group, Postgraduate Program in Nutrition, Federal University of Santa Catarina, Florianopolis, Brazil. ${ }^{5}$ Translational Nutritional Neuroscience Working Group. Postgraduate Program in Nutrition. Department of Nutrition, Universidade Federal de Santa Catarina. Centro de Ciências da Saúde, Campus Universitário - Trindade, Florianópolis, Santa Catarina 88040-900, Brazil.

Received: 6 August 2020 Accepted: 27 October 2020

Published online: 14 November 2020

\section{References}

1. World Health Organization. Depression and other common mental disorders: global health estimates. Geneva: World Health Organization; 2017. p. 27. [citado 31 de julho de 2019]. Disponível em: http://www.who.int/ mental_health/management/depression/prevalence_global_health_ estimates/en/.

2. James SL, Abate D, Abate KH, Abay SM, Abbafati C, Abbasi N, et al. Global, regional, and national incidence, prevalence, and years lived with disability for 354 diseases and injuries for 195 countries and territories, 1990-2017: a systematic analysis for the Global Burden of Disease Study 2017. Lancet. 2018;392(10159):1789-858.

3. Chisholm D, Sweeny K, Sheehan P, Rasmussen B, Smit F, Cuijpers P, et al. Scaling-up treatment of depression and anxiety: a global return on investment analysis. Lancet Psychiatry. 2016;3(5):415-24.

4. DiLuca M, Olesen J. The cost of brain diseases: a burden or a challenge? Neuron. 2014;82(6):1205-8.

5. Avasthi A, Grover S. Clinical practice guidelines for management of depression in elderly. Indian J Psychiatry. 2018;60(Suppl 3):S341-62.

6. Brandão DJ, Fontenelle LF, da Silva SA, Menezes PR, Pastor-Valero M. Depression and excess mortality in the elderly living in low- and middleincome countries: systematic review and meta-analysis. Int J Geriatr Psychiatry. 2019;34(1):22-30.

7. Köhler CA, Evangelou E, Stubbs B, Solmi M, Veronese N, Belbasis L, et al. Mapping risk factors for depression across the lifespan: an umbrella review of evidence from meta-analyses and Mendelian randomization studies. J Psychiatr Res. 2018;103:189-207.

8. Kaltenboeck A, Harmer C. The neuroscience of depressive disorders: a brief review of the past and some considerations about the future. Brain Neurosci Adv. 2018;2:2398212818799269.

9. Otte C, Gold SM, Penninx BW, Pariante CM, Etkin A, Fava M, et al. Major depressive disorder. Nat Rev Dis Primer. 2016;2:16065.

10. Camargo A, Dalmagro AP, Rikel L, da Silva EB, Simao da Silva KAB, Zeni ALB. Cholecalciferol counteracts depressive-like behavior and oxidative stress induced by repeated corticosterone treatment in mice. Eur J Pharmacol. 2018:833:451-61.

11. Fedotova J, Dudnichenko T, Kruzliak P, Puchavskaya Z. Different effects of vitamin $\mathrm{D}$ hormone treatment on depression-like behavior in the adult ovariectomized female rats. Biomed Pharmacother Biomedecine Pharmacother. 2016;84:1865-72.

12. Menon $V$, Kar SK, Suthar N, Nebhinani N. Vitamin D and depression: a critical appraisal of the evidence and future directions. Indian J Psychol Med. 2020;42(1):11-21.

13. Eyles DW, Burne THJ, MCGrath JJ. Vitamin D, effects on brain development, adult brain function and the links between low levels of vitamin $D$ and neuropsychiatric disease. Front Neuroendocrinol. 2013;34(1):47-64.

14. Mayne PE, Burne THJ. Vitamin D in synaptic plasticity, cognitive function, and neuropsychiatric illness. Trends Neurosci. 2019;42(4):293-306.
15. Eyles DW, Smith S, Kinobe R, Hewison M, McGrath JJ. Distribution of the Vitamin $\mathrm{D}$ receptor and 1a-hydroxylase in human brain. J Chem Neuroanat. 2005;29(1):21-30.

16. Stumpf WE, Sar M, Clark SA, DeLuca HF. Brain target sites for 1,25dihydroxyvitamin D3. Science. 1982;215(4538):1403-5.

17. DeLuca GC, Kimball SM, Kolasinski J, Ramagopalan SV, Ebers GC. Review: The role of vitamin $D$ in nervous system health and disease. Neuropathol Appl Neurobiol. 2013;39(5):458-84.

18. Landel V, Stephan D, Cui X, Eyles D, Feron F. Differential expression of vitamin D-associated enzymes and receptors in brain cell subtypes. J Steroid Biochem Mol Biol. 2018;177:129-34.

19. Patrick RP, Ames BN. Vitamin D and the omega-3 fatty acids control serotonin synthesis and action, part 2: relevance for ADHD, bipolar disorder, schizophrenia, and impulsive behavior. FASEB J. 2015;29(6):2207-22.

20. Alghamdi S, Alsulami N, Khoja S, Alsufiani H, Tayeb HO, Tarazi Fl. Vitamin D supplementation ameliorates severity of major depressive disorder. J Mol Neurosci. 2020;70(2):230-5.

21. Kaneko I, Sabir MS, Dussik CM, Whitfield GK, Karrys A, Hsieh J-C, et al. 1,25Dihydroxyvitamin D regulates expression of the tryptophan hydroxylase 2 and leptin genes: implication for behavioral influences of vitamin D. FASEB J. 2015;29(9):4023-35.

22. Sabir MS, Haussler MR, Mallick S, Kaneko I, Lucas DA, Haussler CA, et al. Optimal vitamin D spurs serotonin: 1,25-dihydroxyvitamin D represses serotonin reuptake transport (SERT) and degradation (MAO-A) gene expression in cultured rat serotonergic neuronal cell lines. Genes Nutr. 2018; 13 [citado $1^{\circ}$ de outubro de 2020]. Disponível em: https://www.ncbi.nlm. nih.gov/pmc/articles/PMC6042449/.

23. Berridge MJ. Vitamin D and depression: cellular and regulatory mechanisms. Pharmacol Rev. 2017;69(2):80-92.

24. Berk M, Williams $L$, Jacka FN, O'Neil A, Pasco JA, Moylan S, et al. So depression is an inflammatory disease, but where does the inflammation come from? BMC Med. 2013;11:200.

25. Sibille E. Molecular aging of the brain, neuroplasticity, and vulnerability to depression and other brain-related disorders. Dialogues Clin Neurosci. 2013; 15(1):53-65.

26. Pomatto $L C D$, Davies KJA. The role of declining adaptive homeostasis in ageing. J Physiol. 2017;595(24):7275-309.

27. World Health Organization. Depression. 2020 [citado 13 de fevereiro de 2020]. Disponivel em: https:/www.who.int/news-room/fact-sheets/detail/depression.

28. Lopes CS, Hellwig N, e Silva G de A, Menezes PR. Inequities in access to depression treatment: results of the Brazilian National Health Survey - PNS. Int J Equity Health. 2016;15(1):154.

29. MacLaughlin J, Holick MF. Aging decreases the capacity of human skin to produce vitamin D3. J Clin Invest. 1985;76(4):1536-8.

30. Arabi A, El Rassi R, El-Hajj Fuleihan G. Hypovitaminosis D in developing countries-prevalence, risk factors and outcomes. Nat Rev Endocrinol. 2010; 6(10):550-61.

31. Ju S-Y, Lee Y-J, Jeong S-N. Serum 25-hydroxyvitamin D levels and the risk of depression: A systematic review and meta-analysis. J Nutr Health Aging. 2013;17(5):447-55.

32. Li H, Sun D, Wang A, Pan H, Feng W, Ng CH, et al. Serum 25Hydroxyvitamin D Levels and Depression in Older Adults: A Dose-Response Meta-Analysis of Prospective Cohort Studies. Am J Geriatr Psychiatry. 2019; 27(11):1192-202.

33. Wong SK, Ima-Nirwana* K-YC and S. Vitamin D and Depression: The Evidence from an Indirect Clue to Treatment Strategy. Curr Drug Targets. 2018; [citado 7 de julho de 2019]. Disponível em: http://www.eurekaselect. com/155568/article.

34. Schneider IJC, Confortin SC, Bernardo C de O, Bolsoni CC, Antes DL, Pereira KG, et al. EpiFloripa Aging cohort study: methods, operational aspects, and follow-up strategies. Rev Saúde Pública. 2017;51 [citado 29 de abril de 2019]. Disponível em: http://www.scielo.br/scielo.php?script=sci_ abstract\&pid=S0034-89102017000100290\&lng=en\&nrm=iso\&tlng=en.

35. Confortin SC, Schneider IJC, Danielewicz AL, Fassula AS, de Souza BB, dos Santos CES, et al. Estudo Longitudinal EpiFloripa Idoso - Rotinas de organização e protocolos referentes à coleta, análise e armazenamento de material biológico, exames de imagem e capacidade físico-funcional. Cad Saúde Coletiva. 2019;27(2):210-24.

36. Almeida OP, Almeida SA. Confiabilidade da versão brasileira da Escala de Depressão em Geriatria (GDS) versão reduzida. Arq Neuropsiquiatr. 1999; 57(2B):421-6. 
37. Paradela EMP, Lourenço RA, Veras RP. Validation of geriatric depression scale in a general outpatient clinic. Rev Saúde Pública. 2005;39(6):918-23.

38. BRASIL. Ministério da Saúde. CADERNOS DE ATENÇÃO BÁSICA 19 Envelhecimento e saúde da pessoa idosa: DF: Mnistério da Saúde; 2006. Disponível em: http://bvsms.saude.gov.br/bvs/publicacoes/evelhecimento_ saude_pessoa_idosa.pdf.

39. Almeida OP, Almeida SA. Short versions of the geriatric depression scale: a study of their validity for the diagnosis of a major depressive episode according to ICD-10 and DSM-IV. Int J Geriatr Psychiatry. 1999;14(10):858-65.

40. Ersfeld DL, Rao DS, Body J-J, Sackrison JL, Miller AB, Parikh N, et al. Analytical and clinical validation of the $25 \mathrm{OH}$ vitamin D assay for the LIAISON ${ }^{\circledR}$ automated analyzer. Clin Biochem. 2004;37(10):867-74.

41. Bianchi S, Maffei S, Prontera C, Battaglia D, Vassalle C. Preanalytical, analytical (DiaSorin LIAISON) and clinical variables potentially affecting the $25-\mathrm{OH}$ Vitamin D estimation. Clin Biochem. 2012;45(18):1652-7.

42. Holick MF, Binkley NC, Bischoff-Ferrari HA, Gordon CM, Hanley DA, Heaney $\mathrm{RP}$, et al. Evaluation, Treatment, and Prevention of Vitamin D Deficiency: an Endocrine Society Clinical Practice Guideline. J Clin Endocrinol Metab. 2011; 96(7):1911-30

43. Babor TF, Higgins-Biddle JC, Saunders JB, Monteiro MG. The alcohol use disorders identification test: guidelines for use in primary care. 2001;2:41

44. Benedetti TB, Mazo GZ, de Barros MVG. Application of the International Physical Activity Questionnaire (IPAQ) for evaluation of elderly women: concurrent validity and test-retest reprodutibility. Rev Bras Ciênc Mov. 2004; 12(1):25-34.

45. Benedetti TRB, Antunes P de C, Rodriguez-Añez CR, Mazo GZ, Petroski ÉL. Reproducibility and validity of the International Physical Activity Questionnaire (IPAQ) in elderly men. Rev Bras Med Esporte. 2007;13(1):11-6.

46. Rosa TE da C, Benício MHD, Latorre M do RD de O, Ramos LR. Determinant factors of functional status among the elderly. Rev Saúde Pública. 2003; 37(1):40-8.

47. Folstein MF, Folstein SE, McHugh PR. "Mini-mental state". A practical method for grading the cognitive state of patients for the clinician. J Psychiatr Res. novembro de 1975;12(3):189-198.

48. Almeida OP. The Mini-Mental State Examination and the Diagnosis of Dementia in Brazil. Arq Neuropsiquiatr. 1998;56(3B):605-12.

49. American Academy of Family Physicians, American Dietetic Association, National Concil On The Aging. Nutrition screening and intervention resources for healthcare professionals working with older adults. In: Nutrition Screening Initiative. Washington DC: American Dietetic Association; 2002.

50. World Health Organization, Collaborating Centre for Drug Statistics Methodology, Norwegian Institute of Public Health. WHOCC - ATC/DDD Index. [citado 20 de dezembro de 2019]. Disponível em: https://www. whocc.no/atc_ddd_index/.

51. Hoogendijk WJG, Lips P, Dik MG, Deeg DJH, Beekman ATF, Penninx BWJH. Depression Is Associated With Decreased 25-Hydroxyvitamin D and Increased Parathyroid Hormone Levels in Older Adults. Arch Gen Psychiatry. 2008;65(5):508-12.

52. Imai CM, Halldorsson Tl, Eiriksdottir G, Cotch MF, Steingrimsdottir L, Thorsdottir I, et al. Depression and serum 25-hydroxyvitamin D in older adults living at northern latitudes - AGES-Reykjavik Study. J Nutr Sci. 2015;4 [citado 24 de fevereiro de 2020]. Disponível em: https://www.ncbi.nlm.nih. gov/pmc/articles/PMC4678766/.

53. Song BM, Kim HC, Rhee Y, Youm Y, Kim CO. Association between serum 25-hydroxyvitamin D concentrations and depressive symptoms in an older Korean population: A cross-sectional study. J Affect Disord. 2016;189:357-64.

54. Stewart R, Hirani V. Relationship Between Vitamin D Levels and Depressive Symptoms in Older Residents From a National Survey Population. Psychosom Med. 2010;72(7):608.

55. Toffanello ED, Sergi G, Veronese N, Perissinotto E, Zambon S, Coin A, et al. Serum 25-hydroxyvitamin $d$ and the onset of late-life depressive mood in older men and women: the Pro.V.A. study. J Gerontol A Biol Sci Med Sci. 2014;69(12):1554-61.

56. Yao Y, Fu S, Zhang H, Li N, Zhu Q, Zhang F, et al. The prevalence of depressive symptoms in Chinese longevous persons and its correlation with vitamin D status. BMC Geriatr. 2018;18(1):198.

57. Almeida OP, Hankey GJ, Yeap BB, Golledge J, Flicker L. Vitamin D concentration and its association with past, current and future depression in older men: The Health In Men Study. Maturitas. 2015;81(1):36-41.
58. Chan R, Chan D, Woo J, Ohlsson C, Mellström D, Kwok T, et al. Association between serum 25-hydroxyvitamin D and psychological health in older Chinese men in a cohort study. J Affect Disord. 2011;130(1):251-9.

59. Brouwer-Brolsma EM, Dhonukshe-Rutten RAM, van Wijngaarden JP, van der Zwaluw NL, Sohl E, In't Veld PH, et al. Low vitamin D status is associated with more depressive symptoms in Dutch older adults. Eur J Nutr. 2016; 55(4):1525-34.

60. Lapid MI, Cha SS, Takahashi PY. Vitamin D and depression in geriatric primary care patients. Clin Interv Aging. 2013;8:509-14.

61. Sherchand O, Sapkota N, Chaudhari RK, Khan SA, Baranwal JK, Pokhrel T, et al. Association between vitamin D deficiency and depression in Nepalese population. Psychiatry Res. 2018;267:266-71.

62. Vidgren M, Virtanen JK, Tolmunen T, Nurmi T, Tuomainen T-P, Voutilainen S, et al. Serum Concentrations of 25-Hydroxyvitamin D and Depression in a General Middle-Aged to Elderly Population in Finland. J Nutr Health Aging. 2018;22(1):159-64.

63. de Oliveira C, Hirani V, Biddulph JP. Associations Between Vitamin D Levels and Depressive Symptoms in Later Life: Evidence From the English Longitudinal Study of Ageing (ELSA). J Gerontol Ser A. 2018;73(10):1377-82.

64. Jovanova O, Aarts N, Noordam R, Carola-Zillikens M, Hofman A, Tiemeier H. Vitamin $D$ serum levels are cross-sectionally but not prospectively associated with late-life depression. Acta Psychiatr Scand. 2017;135(3):18594.

65. Lee S-H, Suh E, Park K-C, Haam J-H, Kim K, Koo HS, et al. Association of serum 25-hydroxyvitamin $\mathrm{D}$ and serum total cholesterol with depressive symptoms in Korean adults: the Fifth Korean National Health and Nutrition Examination Survey (KNHANES V, 2010-2012). Public Health Nutr. 2017; 20(10):1836-43.

66. Shin Y-C, Jung C-H, Kim H-J, Kim E-J, Lim S-W. The associations among vitamin D deficiency, C-reactive protein, and depressive symptoms. J Psychosom Res. 2016;90:98-104.

67. Rabenberg M, Harisch C, Rieckmann N, Buttery AK, Mensink GBM, Busch MA Association between vitamin $D$ and depressive symptoms varies by season: Results from the German Health Interview and Examination Survey for Adults (DEGS1). J Affect Disord. 2016;204:92-8.

68. Józefowicz O, Rabe-Jabłońska J, Woźniacka A, Strzelecki D. Analysis of vitamin D status in major depression. J Psychiatr Pract. 2014;20(5):329-37.

69. Milaneschi Y, Hoogendijk W, Lips P, Heijboer AC, Schoevers R, van Hemert $A M$, et al. The association between low vitamin $D$ and depressive disorders. Mol Psychiatry. 2014;19(4):444-51.

70. Lee DM, Tajar A, O'Neill TW, O'Connor DB, Bartfai G, Boonen S, et al. Lower vitamin $D$ levels are associated with depression among communitydwelling European men. J Psychopharmacol (Oxf). 2011;25(10):1320-8.

71. Nanri A, Mizoue T, Matsushita Y, Poudel-Tandukar K, Sato M, Ohta M, et al. Association between serum 25-hydroxyvitamin D and depressive symptoms in Japanese: analysis by survey season. Eur J Clin Nutr. 2009;63(12):1444-7.

72. Pan A, Lu L, Franco OH, Yu Z, Li H, Lin X. Association between depressive symptoms and 25-hydroxyvitamin D in middle-aged and elderly Chinese. J Affect Disord. 2009;118(1):240-3.

73. de Koning EJ, Elstgeest LEM, Comijs HC, Lips P, Rijnhart JJM, van Marwijk HWJ, et al. Vitamin D Status and Depressive Symptoms in Older Adults: A Role for Physical Functioning? Am J Geriatr Psychiatry. 2018;26(11):1131-43.

74. Lotfaliany M, Hoare E, Jacka FN, Kowal P, Berk M, Mohebbi M. Variation in the prevalence of depression and patterns of association, sociodemographic and lifestyle factors in community-dwelling older adults in six low- and middle-income countries. J Affect Disord. 2019;251:218-26.

75. Lorant V, Deliège D, Eaton W, Robert A, Philippot P, Ansseau M. Socioeconomic Inequalities in Depression: A Meta-Analysis. Am J Epidemiol. 2003;157(2):98-112.

76. Holick MF. Vitamin D Deficiency. N Engl J Med. 2007;357(3):266-81.

77. Hayes DP. Vitamin D and ageing. Biogerontology. 2010;11(1):1-16.

78. Boucher BJ. The Problems of Vitamin D Insufficiency in Older People. Aging Dis. 2012;3(4):313-29.

79. Schuch FB, Vancampfort D, Firth J, Rosenbaum S, Ward PB, Silva ES, et al. Physical Activity and Incident Depression: A Meta-Analysis of Prospective Cohort Studies. Am J Psychiatry. 2018;175(7):631-48.

80. Milaneschi Y, Shardell M, Corsi AM, Vazzana R, Bandinelli S, Guralnik JM, et al. Serum 25-hydroxyvitamin D and depressive symptoms in older women and men. J Clin Endocrinol Metab. 2010;95(7):3225-33.

81. Wortsman J, Matsuoka LY, Chen TC, Lu Z, Holick MF, et al. Am J Clin Nutr. 2000;72(3):690-3. 
82. Snijder MB, van Dam RM, Visser M, Deeg DJH, Dekker JM, Bouter LM, et al. Adiposity in Relation to Vitamin D Status and Parathyroid Hormone Levels: A Population-Based Study in Older Men and Women. J Clin Endocrinol Metab. 2005;90(7):4119-23.

83. Al-Harbi KS. Treatment-resistant depression: therapeutic trends, challenges, and future directions. Patient Prefer Adherence. 2012;6:369-88.

84. Jaffe $\mathrm{DH}$, Rive $\mathrm{B}$, Denee TR. The humanistic and economic burden of treatment-resistant depression in Europe: a cross-sectional study. BMC Psychiatry. 2019;19(1):247.

85. Johnston KM, Powell LC, Anderson IM, Szabo S, Cline S. The burden of treatment-resistant depression: A systematic review of the economic and quality of life literature. J Affect Disord. 2019;242:195-210.

86. Horne R. Representations of medication and treatment: Advances in theory and measurement. In: Perceptions of health and illness: Current research and applications. Amsterdam: Harwood Academic Publishers; 1997. p. 155-88.

87. Oude Voshaar RC, Derks WJ, Comijs HC, Schoevers RA, de Borst MH, Marijnissen RM. Antidepressants differentially related to 1,25-(OH)2 vitamin D3 and 25-(OH) vitamin D3 in late-life depression. Transl Psychiatry. 2014; 4(4)::383.

88. Fond G, Faugere M, Faget-Agius C, Cermolacce M, Richieri R, Boyer L, et al. Hypovitaminosis $D$ is associated with negative symptoms, suicide risk, agoraphobia, impaired functional remission, and antidepressant consumption in schizophrenia. Eur Arch Psychiatry Clin Neurosci. 2019; 269(8):879-86.

89. Vellekkatt $F$, Menon V. Efficacy of vitamin D supplementation in major depression: A meta-analysis of randomized controlled trials. J Postgrad Med. 2019;65(2):74-80.

90. Alavi NM, Khademalhoseini S, Vakili Z, Assarian F. Effect of vitamin D supplementation on depression in elderly patients: A randomized clinical trial. Clin Nutr. 2019;38(5):2065-70.

91. Singh S, Sharma P, Gautam V. Role of vitamin D supplementation as adjunctive therapy to escitalopram in patients of major depressive disorder: a 8 week prospective, randomized, interventional, clinical study. Int J Basic Clin Pharmacol. 2019;8(8):1713-6.

92. Khoraminya N, Tehrani-Doost M, Jazayeri S, Hosseini A, Djazayery A. Efeitos terapêuticos da vitamina D como terapia adjuvante à fluoxetina em pacientes com transtorno depressivo maior. Aust N Z J Psychiatry. 2013; 47(3):271-5

93. Spedding S. Vitamin D and Depression: A Systematic Review and MetaAnalysis Comparing Studies with and without Biological Flaws. Nutrients. 2014;6(4):1501-18.

94. de Koning EJ, Lips P, Penninx BWJH, Elders PJM, Heijboer AC, den Heijer M, et al. Vitamin $D$ supplementation for the prevention of depression and poor physical function in older persons: the D-Vitaal study, a randomized clinical trial. Am J Clin Nutr. 2019;110(5):1119-30.

95. Jorde R, Kubiak J. No improvement in depressive symptoms by vitamin $D$ supplementation: results from a randomised controlled trial. J Nutr Sci. 2018;7:e30.

96. Wang PS, Aguilar-Gaxiola S, Alonso J, Angermeyer MC, Borges G, Bromet EJ, et al. Worldwide Use of Mental Health Services for Anxiety, Mood, and Substance Disorders: Results from 17 Countries in the WHO World Mental Health (WMH) Surveys. Lancet. 2007;370(9590):841-50.

97. Ormel J, Cuijpers P, Jorm A, Schoevers RA. What is needed to eradicate the depression epidemic, and why. Ment Health Prev. 2020;17:200177.

\section{Publisher's Note}

Springer Nature remains neutral with regard to jurisdictional claims in published maps and institutional affiliations.

\section{Ready to submit your research? Choose BMC and benefit from:}

- fast, convenient online submission

- thorough peer review by experienced researchers in your field

- rapid publication on acceptance

- support for research data, including large and complex data types

- gold Open Access which fosters wider collaboration and increased citations

- maximum visibility for your research: over $100 \mathrm{M}$ website views per year

At BMC, research is always in progress.

Learn more biomedcentral.com/submissions 